\title{
Correction to: A nanobody-horseradish peroxidase fusion protein-based competitive ELISA for rapid detection of antibodies against porcine circovirus type 2
}

Yang Mu ${ }^{1,2^{*}}$, Cunyu Jia ${ }^{1,2}$, Xu Zheng ${ }^{1,2}$, Haipeng Zhu ${ }^{1,2}$, Xin Zhang ${ }^{1,2}$, Haoran Xu', Baoyuan Liu ${ }^{1,2}$, Qin Zhao ${ }^{1,2}$ and En-Min Zhou ${ }^{1,2^{*}}$ (D)

\section{Correction to: J Nanobiotechnol (2021) 19(1):34}

https://doi.org/10.1186/s12951-021-00778-8

The original version of this article [1], unfortunately contained some errors.

In the Materials and methods, Subheading 'Preparation of rabbit anti-camel IgG antiserum', Paragraph 1, Sentences 7 should read: "Freund's complete adjuvant (Sigma-Aldrich, USA) was used for the first immunization, followed by Freund's incomplete adjuvant."

In the Materials and methods, Subheading 'Panning and identification of PCV2-Cap protein specific

Nanobodies', Paragraph 1, Sentences 3 should read:

"On the next day, after washing with PBS containing 0.05\% Tween-20 (PSB'T, V/V) and blocking with PBS'T containing $2.5 \%$ skim milk (SM-PBS'T, W/V), $5 \times 10^{10}$ PFU rescued phage in $100 \mu \mathrm{L}$ SM-PBS'T was added and incubated for $2 \mathrm{~h}$ at RT."

The authors apologize for these errors.

\begin{abstract}
Author details
${ }^{1}$ Department of Preventive Veterinary Medicine, College of Veterinary Medicine, Northwest A\&F University, Yangling 712100, Shaanxi, China. ${ }^{2}$ Scientific Observing and Experimental Station of Veterinary Pharmacology and Diagnostic Technology, Ministry of Agriculture, Yangling 712100, Shaanxi, China.
\end{abstract}

Published online: 03 March 2021

\section{Reference}

1. Mu Y, Jia C, Zheng X, Zhu H, Zhang X, Xu H, Liu B, Zhao Q, Zhou EM. A nanobody-horseradish peroxidase fusion protein-based competitive ELISA for rapid detection of antibodies against porcine circovirus type 2. J Nanobiotechnol. 2021;19(1):34. https://doi.org/10.1186/s12951-02100778-8.

\section{Publisher's Note}

Springer Nature remains neutral with regard to jurisdictional claims in published maps and institutional affiliations.

(C) The Author(s) 2021. This article is licensed under a Creative Commons Attribution 4.0 International License, which permits use, sharing, adaptation, distribution and reproduction in any medium or format, as long as you give appropriate credit to the original author(s) and the source, provide a link to the Creative Commons licence, and indicate if changes were made. The images or other third party material in this article are included in the article's Creative Commons licence, unless indicated otherwise in a credit line to the material. If material is not included in the article's Creative Commons licence and your intended use is not permitted by statutory regulation or exceeds the permitted use, you will need to obtain permission directly from the copyright holder. To view a copy of this licence, visit http://creativecommons.org/licenses/by/4.0/. The Creative Commons Public Domain Dedication waiver (http://creativecommons.org/publicdomain/zero/1.0/) applies to the data made available in this article, unless otherwise stated in a credit line to the data. 